\title{
Mixed fisheries management: protecting the weakest link
}

\author{
J. Batsleer ${ }^{1,2,{ }^{*}, \text { J. J. Poos }{ }^{1} \text {, P. Marchal }{ }^{3}, \text { Y. Vermard }{ }^{3} \text {, A. D. Rijnsdorp }}{ }^{1,2}$ \\ 1 IMARES, Institute for Marine Resources and Ecosystem Studies, PO Box 68, 1970 AB IJmuiden, The \\ Netherlands \\ ${ }^{2}$ Aquaculture and Fisheries Group, Wageningen University, PO Box 338, $6700 \mathrm{AH}$ Wageningen, The Netherlands \\ 3 IFREMER, Channel and North Sea Fisheries Unit, 150 Quai Gambetta, BP 699, Boulogne-sur-Mer 62321,
} France

*: Corresponding author : J. Batsleer, email address : jurgen.batsleer@wur.nl

\begin{abstract}
:
North Sea cod Gadus morhua stock is outside safe biological limits, and total allowable catch (TAC) management has proved ineffective to rebuild the stock. The European Commission is considering the imposition of a discard ban to preserve vulnerable and economically important fish stocks. We explored the potential effects of a discard ban in mixed fisheries management using the French mixed fisheries in the Eastern English Channel as a model system. We examined in particular the performance of 2 different management scenarios: (1) individual quota management with a tolerance for discarding and (2) individual quota management in combination with a discard ban, using a dynamic state variable model. The model evaluates a time series of decisions taken by fishers to maximize profits within management constraints. Compliance to management was tested by applying an in-height varying fine for exceeding the quota. We then evaluated the consequences of individual cod quota in both scenarios with respect to over-quota discarding, spatial and temporal effort allocation and switching between métiers. Individual quota management without a discard ban hardly influenced fishers' behaviour as they could fully utilise cod quota and continue fishing other species while discarding cod. In contrast, a discard ban forced fishers to reallocate effort to areas and weeks in which cod catch is low, at the expense of lower revenue. In general, a restrictive policy for individual quota for cod needs to be combined with a discard ban and a high fine ( $>20$ times the sale price) to reduce over-quota discarding.
\end{abstract}

Keywords: Discard ban ; TAC ; Dynamic State Variable Modelling ; Eastern English Channel ; Cod ; Gadus morhua; Mixed fisheries ; Fleet dynamics 


\section{Introduction}

Fishing is an important socio-economic activity providing food and employment (FAO 2008) but is criticized because of its adverse impact on exploited fish stocks and marine ecosystems. In this context, throwing overboard dead fish that have been caught in the net ("discarding") is often considered a wasteful practice that has adverse effects on fish stocks while not contributing to the harvesting of food (Alverson et al. 1994, Kelleher 20051).

Discarding is mainly driven by economics and management. From an economic perspective, low valued fish of quota species are discarded (high-grading) in the expectation to catch more valued fish later (Gillis et al. 1995b), while regulation of mesh size and minimum landing size determine the discarding of undersized fish (Cappell 2001, Graham \& Fryer 2006). TAC regulations also create an incentive for fishers to discard the over-quota caught fish, especially in mixed fisheries (Daan, 1997, Reis, 2010), and they have often proved unable to control fishing mortality around sustainable levels (Ulrich et al. 2011).

Discard reduction is high on the agenda of EU fisheries managers and the European Commission is implementing a discard ban. Under a discard ban, all catches of both target and by-catch species should be landed and will be deducted from the individual quotas. A discard ban in combination with individual, and possibly transferable, quota (ITQ) aims to prevent the waste of food, reduce fishing impacts on the ecosystem, preserve vulnerable and economically important fish stocks and improve scientific advice (Anon. 2011, Buisman et al. 2011). Despite of the implementation of ITQ management with a discard ban in some countries, few studies have address the performance of this combination. Yet, results have shown that discarding, albeit at a significantly lower level, still occurs, but that the ban can aid to the recovery of exploited stocks (Kristofersson \& Rickertsen 2005, 2009, Diamond \& Beukers-Stewart 2011). 
Given prevalent management regulations, fishers are expected to adjust their behaviour to maximise their utility (Gordon 1953, Hilborn \& Kennedy 1992). Hence, fishers may respond to management regulations by trading-off economic gain against the cost of non-compliance. Adaptive behaviour of fishers, e.g. reallocation of effort to other species, fishing grounds or seasons, is an important management concern (Salas \& Gaertner 2004, Poos et al. 2010). Further studies on adaptive behaviour of fishers may be useful to explore the scope for responses that undermine the effectiveness of a certain management system. A fisheries manager needs to trade-off socio-economic benefits of a fishery against protection of the weakest links in the ecosystem. Unveiling these trade-offs will support fisheries management. This paper describes how a discard ban in combination with individual quota may improve the regulation of fishing mortality for a depleted stock that is exploited in a mixed fishery. Using a dynamic state variable model (DSVM; Clark \& Mangel 2000), we study the overquota discarding of cod (Gadus morhua) in the eastern English Channel and the southern North Sea. Despite signs of recovery following the recovery plan imposed in 2003 the stock has remained the weakest component of the demersal fish assemblage (Ulrich et al. 2011, Kraak et al. 2012). We compare the performance of (i) quota management that allows overquota discarding and (ii) quota management in combination with a discard ban, using the French otter trawl and net fisheries as a case study. The consequences of individual quota for cod in both management regimes are studied based on a number of indicators of the fishery system such as the catch of cod, the spatial and temporal distribution of fishing effort, the changes in métiers and the economic performance of the fishery.

\section{Material and Methods}

\section{The English Channel mixed fisheries}

The English Channel is a co rridor between the Atlantic and the North Sea. The eastern English Channel (ICES division VIId) is the narrowest part of the Channel and it is an 
important fishing area (Vaz et al. 2007). The French fishing fleets are most active in this area with a total of 641 vessels in 2005 , landing over 90,000 tons of fish with a total value of 218 million euros. Boulogne-Sur-Mer is the main French fishing harbour, both in number of vessels and total landings (Carpentier et al. 2009).

\section{Data}

Effort and landings data from logbooks and sales slips were made available over the period 2001 - 2005. The data set included information by fishing trip on ve ssel length, vessel tonnage, engine power, gear type, mesh size, fishing ground (ICES rectangle, $1^{\circ}$ longitude $\mathrm{x}$ $0.5^{\circ}$ latitude, approximately $30 \times 30$ nautical miles), fishing effort (hours fished for trawlers, days absent from port for netters), weight and value of the landings per species. We selected two fleets: the French otter trawl fleet and netting fleet. These fleets fish in the eastern English Channel and most southern part of the North Sea between $49^{\circ} \mathrm{N}, 2^{\circ} \mathrm{W}$ and $52^{\circ} \mathrm{N} 4^{\circ} \mathrm{E}$, for which most data is available (Figure 1).

\section{Otter trawlers}

The otter trawl fleet is one of the main demersal fishing fleets operating in the eastern English Channel. Vessels in this fleet are predominantly rigged with $80 \mathrm{~m} \mathrm{~m}$ mesh size nets (Carpentier et al. 2009). The dataset consists of 120 vessels with an average engine power of $440 \mathrm{~kW}$ and average vessel length of $21 \mathrm{~m}$.

The otter trawl fleet operates two separate métiers using: (i) demersal otter trawls (OTBD, 25591 trips) and, (ii) mixed demersal/pelagic trawls (OTBM, 725 trips). Métiers are derived from the observed landings and largely based on DCF level 5 metiers (Ulrich et al. 2012). Both métiers land a mix of species, of which whiting, cod, plaice, sole, mackerel and mullet make up $65 \%$. Whiting and mackerel contribute to the bulk of landings of OTBD and OTBM, respectively (Table 1). Fishers are capable of switching métiers during the year. Both métiers 
are operated inside and outside the 12 nautical mile zone (Carpentier et al. 2009), with fishing grounds in ICES rectangles $30 \mathrm{~F} 1$ and $29 \mathrm{~F} 0$ being the most frequently visited.

\section{Static netters}

The netting fleet in the study area consists of 107 vessels, with an average engine power of $160 \mathrm{~kW}$ and average length of $12 \mathrm{~m}$. The most common gear is the trammel net (TN, 10449 trips), being used interchangeably with gillnets (GN, 632 trips) (Carpentier 2009). Both nets are anchored to the bottom but differ in their structure and target species. Trammel nets have three sets of netting, of which the outer nets have a large mesh and the inner net has a small mesh size, whereas gillnets have only one net. This difference makes trammel nets less selective in terms of size and variety of fish species caught (Carpentier et al. 2009). The most commonly used mesh size for both nets is $90 \mathrm{~mm}$, used mainly to catch sole; however, larger mesh sizes $(100 \mathrm{~mm}-180 \mathrm{~mm})$ may be used when plaice or cod are targeted. Although sole, plaice, and cod are the main target species and account for approximately $80 \%$ of the landings, sole is the main target species for trammel nets, whereas cod is the primary target species for gill-netters. Most netting activities occur close to the port of Boulogne-Sur-Mer (30F1, 31F2). A few (2.7\%) observations in the data set consisted of multiple aggregated trips, and these were not included in the analysis.

\section{Statistical analysis}

Our aim is to parameterize a simulation model by estimating the spatial and temporal distribution of landings per unit effort $\left(l_{i}\right)$ of six species: plaice (Pleuronectes platessa), sole (Solea solea), cod (Gadus morhua), whiting (Merlangius merlangus), Atlantic mackerel (Scomber scombrus) and mullet (Mullus spp.). Our dataset contains measurements of landings $\left(y_{i}\right)$ in weight $(\mathrm{kg})$ by species and fishing effort $\left(E_{i}\right)$ per trip $i$;

$$
l_{i}=\frac{y_{i}}{E_{i}}
$$


We apply Generalized Additive Models (GAMs) to allow for non-linearity in the relationships between the response variable and multiple explanatory variables (Wood 2006, Zuur et al. 2009). The actual value of the landings per trip is used as the response variable while the fishing effort serves as offset. By analysing the six species separately, we ignore potential covariance structure among species. We use the negative binomial distribution with a logarithmic link function to correct for over-dispersion while allowing zero-observations. The logarithmic link ensures the fitted values are always non-negative (Zuur et al. 2009).

$$
\begin{aligned}
& y_{i} \sim \text { Negative Binomial }\left(\mu_{i}, \theta\right) \\
& \mu_{i}=l_{i} E_{i}=e^{\eta_{i}} E_{i}=e^{\eta_{i}+\log \left(E_{i}\right)}
\end{aligned}
$$

Here, $\mu_{i}$ is the expected landings per trip and $\theta$ is the dispersion parameter, which accounts for under- or over-dispersion. $\log \left(E_{i}\right)$ is the known offset and $\eta_{i}$ is the linear predictor modelled as

$$
\begin{aligned}
& \eta_{i}=\text { métiers }+ \text { year }+f(\text { engine powerlfleet })+f(\text { mesh sizelfleet })+f(\text { DoY })+ \\
& f(\text { lat }, \text { lon })+f(\text { lat,lon,DoY })
\end{aligned}
$$

Métiers and year were entered as discrete variables (Table 2$)$. The term $f$ (engine power|fleet) are for estimating the smooth function of engine power by tactic and $f$ (mesh size fleet) for mesh size by tactic. fleet is a term indicating the difference between trawlers and netters. $f(D o Y)$ and $f($ lat,lon) indicate the main effects of day of the year (DoY) and space (latitude and longitude based on geographic midpoint of the ICES rectangle) are fit. $f($ lat,lon,DoY) is the spline for the interaction term of latitude, longitude and DoY. The main effects and the interaction between latitude, longitude and DoY are included to model the seasonal changes in distribution. We limited the number of knots in each smoothing to reduce the possibility of over-fitting (Table 2). Because vessel length and engine power are highly correlated, we decided to only include engine power because of its presumed larger influence on the catch 
efficiency (Rijnsdorp et al. 2006). Mesh size was included as it ma y indicate the target species, i.e. the predominant $80 \mathrm{~mm}$ and $90 \mathrm{~mm}$ mesh sizes to target whiting and sole for otter trawls and trammel nets respectively, while larger mesh sizes $(120 \mathrm{~mm}-180 \mathrm{~mm})$ are fitted when targeting cod. Finally, the variable year was used to capture differences in landings per unit of effort between the years.

Forward selection based on the Bayesian Information Criterion (BIC) is used to select a model for each species. Forward selection starts with an empty model, fitted with the intercept only. Then covariates are added sequentially based on the BIC in order to obtain the "best" model. The results of the best model were used to predict the spatial and temporal patterns in catch rates for each of the species and vessel-gear combinations to be used in the simulation model.

\section{Simulation Model}

Our model is based on Dynamic State Variable Modelling (DSVM) (Houston \& McNamara 1999, Clark \& Mangel 2000). The DSVM is an individual based model that has been used to predict behaviour of animals (Mangel 1987, Clark \& Butler 1999) as well as fishers (Gillis et al. 1995b, Poos et al. 2010, Dowling et al. 2011). We expanded the model of Poos et al. (2010) in which each individual vessel in the model has a set of choices, allowing it to respond to management regulations and economic opportunities. In the expanded model individuals choose simultaneously: (1) to go out to fish or to stay in port, (2) a métier, (3) a fishing ground and (4) to discard or land the catch.

A vessel evaluates its optimal annual strategy in terms of biweekly behavioural choices, based on a utility function. We use the annual net revenue $(\varphi)$ as the utility that a fisher wants to optimize (Gordon 1953,Poos et al. 2010). 
The annual net revenue is defined as the total quantity landed of each species $\left(L_{s}\right)$ weighted by each species price $\left(p_{s}\right)$ minus the variable fishing costs and a fine for overshooting the quota.

$$
\varphi\left(L_{1-6}, E\right)=\sum_{s=1}^{6}\left(L_{s} p_{s}\right)-\left(E p_{e}+D\left(L_{s}\right)\right)
$$

Variable fishing costs consist of total fuel cost; i.e. total effort (days) $(E)$ times fuel costs per day $\left(€ /\right.$ day) $\left(p_{e}\right)$. The fine for overshooting the quota $\left(D\left(L_{s}\right)\right)$ is zero as long as landings are within quota, and increase linearly with over-quota landings. Given the utility function at the end of the year, the dynamic programming equation is used to calculate the optimal decision in each time step given the state of the individual. In our case, the state is determined by the uptake of the cod quota, landings of the five other species, and the fishing effort. All vessels within a fleet are equal at the beginning of the year. As a result of the variability in catch rates in the model, the vessels will differ in their state as time progresses. The details for this procedure can be found in Poos et al. 2010.

Compliance to management was tested by exploring the effect of different fine values. Fines (in euro per $\mathrm{kg}$ ) increased from one to twenty times the cod price per $\mathrm{kg}$. These fines are equivalent to those imposed for catching abalones illegally, i.e. ten times landing price (Bose \& Crees-Morris 2009).

For each time step, a vessel chooses a métier and one fishing ground (out of 20) based on the optimal choice given the vessels state. Each combination of métier and fishing ground within a time step is characterized by a mean $(\mu)$ and variance $(\theta)$ of the catch rates for each species estimated by the GAM. Biweekly catch rates were calculated from the GAM results by setting the offset equal to the average fishing effort for trawlers or netters within two-week periods. The catch rates are assumed independent of previous fishing activities in that area. We arbitrarily chose 2005 as a basis of our simulations. Further parameterisation of the 
model in terms of variable costs was done assuming Boulogne-Sur-Mer was the home harbour of the vessels.

The combination of métier and fishing ground determines the amount of effort required for the fishing operation. Fishing effort consists of the summed actual fishing time and travel time required to reach the fishing ground. The average fishing time was estimated from the 2001 data at 3.1 days for a trawler and 3 da ys for a netter. Travel time depends on the distance from port and was calculated from the distance in nautical miles (Nm) in a straight line from the harbour of Boulogne-Sur-Mer to each fishing ground. Assuming a steaming speed of 10 nautical miles per hour for an otter trawl and 6 nautical miles per hour for a netter (Messina \& Notti 2007) and taking account of the number of trips observed per time step (2week period), we calculated the travel time needed to reach a fishing ground. If a fisher decides to stay in the harbour, nothing is caught and no effort is used.

The costs associated with using fishing effort depend on the fuel use in the model. Fuel costs per day are estimated to be $2100 €$ for trawlers and $1600 €$ for netters and are equivalent to approximately $35 \%$ of the gross revenue (Taal et al. 2009). The final element for the parameterization is the market value of the target species. We choose to use fixed market values for each species, determined by the average price per $\mathrm{kg}$ within our dataset. Table 3 provides detailed information on the parameters and their values used in the model.

\section{Management scenarios}

This study compares the performance of individual cod quota (IQ) management combined with two discard scenarios for both fisheries: (1) over-quota discarding is allowed; (2) overquota discarding is not allowed (discard ban) (Table 4). Individual cod quota gradually increase from zero to 27 tons for trawlers and zero to 20 tons for netters. In addition, different fine values are used to test the compliance of trawlers to the imposed discard ban.

\section{Results}




\section{Statistical analyses}

For each species, forward selection based on BIC result in all main and interactions to be selected in the final model (Table 5). All GAM models exhibit similarities in selecting covariates best explaining the variation in landings. The model for whiting, besides having the lowest $(28.3 \%)$ explained deviance, diverges from the other models because the day of year as a main effect did not improve the model.

Within the cod model, mesh size was added as first variable, which confirms our expectations that larger mesh sizes are preferred when fishing for cod. A remarkable result for cod is that landings are significantly $(\mathrm{p}<0.001)$ lower in the years 2004 and 2005. Lower landings are likely related to the low abundances and weak recruitments of cod during that period (ICES 2010). For plaice, whiting and mullet, the variable engine power was selected and added as first variable in explaining the landings. The first variable selected for mackerel and sole is métiers. This result confirms our chosen métiers classifications, whereby mackerel is mainly targeted by mixed demersal/pelagic trawls while sole is the main target species for trammel netters. In addition, for sole the variable engine power is selected as the second variable confirming vessels with low engine power (i.e. netters) target sole. Below, the simulation model results based on the GAM predictions.

\section{Cod catch}

Cod catches depend on the fishing fleet and management scenario (Figure 2). For trawlers, individual cod quota (IQ) lower than 10 tons per year result in full utilization of quota by almost all vessels, while over-quota catches are being discarded. Hence, holding cod catches at a high level (ca. $10 \mathrm{t} \mathrm{y}^{-1}$ ). Increasing IQ above 10 tons results in trawlers progressively being unable to use all their quota: all cod catches (ca. $12 \mathrm{t} \mathrm{y}^{-1}$ ) are landed and none are discarded. The variability in cod catches in the model causes some fishers to be more or less successful catching cod than others. Successful fishers will fully exploit their quota and 
discard their over-quota catch, while less successful fishers will land all their cod catches and will not use all quota. When a discard ban is introduced (in combination with a high fine; $200 € \mathrm{~kg}^{-1}$ ), IQ may reduce catches considerably. At IQ below 4 tons per year, the cod catch is less than a ton per year. Increasing IQ results in an increase in landings, but vessels rarely utilize their quota completely. As for the first scenario, catches level off towards ca. 12 tons per year.

There are two main periods, during which cod is caught by trawlers (Figure 3). The first period is around the end and beginning of the year, while the second period occurs halfway during the year. Fishers constrained by a discard ban switch to other fishing grounds during these periods, resulting in lower annual cod catches.

Despite much lower cod catches $\left(<2 \mathrm{t} \mathrm{y}^{-1}\right)$ for netters (Figure $2 \mathrm{c} \& \mathrm{~d}$ ), similar results are observed as for trawlers. While the netting fleet shows more spatial overlap under both management scenarios, deviations of the choice of fishing grounds occur during periods when cod is more frequently caught (figure $3 \mathrm{~d}$-f). So, netters also switch fishing grounds to avoid catching cod.

When IQ for cod are reasonably high $\left(\sim 9 \mathrm{t}^{-1}\right)$, trawlers only become limited in landing cod at the end of the year, and only discard when quota are almost fully exploited. When less quota is available, the amount of cod being discarded increases and fishers discard earlier in the year as well. When quota are low $\left(\sim 3 \mathrm{t} \mathrm{y}^{-1}\right) \operatorname{cod}$ is discarded throughout the year, with the highest amounts of discards occurring during both periods when cod is mainly caught. Netters barely discard cod due to their low catches. However, if cod is discarded, it occurs at the end of the year during the period when cod catches are higher. These results show that fishers are able to regulate their landings by switching fishing ground, switching métier and discard their over-quota catch. When discarding is banned, fishers can only regulate their landings by switching fishing grounds and targeting other species. 


\section{Effort}

If discarding is allowed, annual allocation of fishing effort of a trawler is independent of the cod quota (Figure 4). The total days at sea (DAS) increase marginally from an average of 108 days to 110 days when more quota becomes available. Effort is mainly allocated near the English coast (30E9) and in the southern North Sea (30F1 and 32F1) (Figure 5). Imposing a discard ban in combination with low IQ has a clear impact on effort and setting IQ to zero results in a complete stop of fishing. At quota below 6 tons, there is a steep increase of effort with increasing quota. As more quota become available the increase in effort slows down and stabilizes towards an average effort of 110 DAS. Introducing a discard ban causes a spatial shift in the distribution of fishing. At low IQ levels, trawlers make fewer trips (21 trips) and effort is concentrated in more southern and distant fishing grounds such as $28 \mathrm{~F} 0,28 \mathrm{~F} 1,30 \mathrm{E} 9$ and 29F0. At a higher IQ level, the spatial distribution resembles that found when discarding is allowed.

In the absence of a discard ban, netters spend 108 days of the year at sea, regardless of the quota. As for trawlers, cod quota management on its own has no influence on the spatial distribution of netters that predominantly fish in the eastern English Channel $(56 \%$ in $28 \mathrm{~F} 1)$. With a discard ban, effort is only influenced at low $\left(<8 \mathrm{t} \mathrm{y}^{-1}\right)$ quota. Fishing stops when IQ is null, but rapidly increases up to 111 DAS when IQ is less than $3 \mathrm{t} \mathrm{y}^{-1}$. Yet effort gradually decreases again and remains fixed at an average annual effort of 107 DAS. The peak at low quota may reflect a reallocation of effort away from the southern North Sea (30F1) to more distant fishing grounds into the eastern English Channel (29E9). At higher IQ levels, spatial distribution of fishing effort is equal to the distribution when discarding is allowed.

The shift in spatial distribution of fishing effort from the southern North Sea to the eastern English Channel is related to the spatial distribution of cod. Cod is more frequently caught in the southern North Sea fishing grounds compared to the Channel. When cod quota is high a 
fisher can continue to fish in the northern fishing grounds until the cod quota becomes depleted. Implementing low cod quota and a discard ban, however, makes Channel fishing grounds more attractive, because of a reduced risk of catching cod, while targeting other commercial fish species.

Besides spatial effort allocation to reduce cod catches, trawlers change their preference for a métier in response to IQ (Figure 6). When constrained by a discard ban and IQ below 4 tons, there is no fishing at all or trips are done only choosing OTBM. As IQ increases, fishers increasingly choose for OTBD ( $0 \%$ to $47 \%)$. An IQ of 27 tons results in similar operation levels as observed for the scenario when discarding is allowed. Also in this scenario, less quota, reduces $(48 \%$ to $28 \%)$ the choice to operate the OTBD métier. Netters choose, regardless of the management scenario, to fish using a trammel net throughout the year.

\section{Catch composition}

For trawlers constrained by a discard ban and low individual cod quota, mackerel is the most dominant $(>90 \%)$ species in the catch supplemented with mullet (ca. $8 \%$ ) and plaice $(1 \%)$ (figure 7). With increasing IQ, whiting catches gradually increase (0\%-53\%), while the proportion of mackerel in the catch decreases ( $>90 \%$ to. $40 \%)$. Other species such as mullet $(4 \%), \operatorname{cod}(3 \%)$ and plaice $(<1 \%)$ contribute marginally to the catches.

For netters there is virtually no change in the catch composition with changing IQ. Allowing discards eliminates the effect of low IQ on the catch composition. For trawlers, whiting and mackerel are the main contributors whether a low or high cod quota is implemented. Yet, less quota ensures a slight decrease in whiting and a small increase in the proportion of mackerel. Netters mainly catch sole $(>80 \%)$ and plaice $(\sim 18 \%)$, while cod is caught in small quantities and contributes less than $1 \%$ to the entire catch. Hence, introducing a discard ban on top of individual cod quota has little impact on the catch composition of netters.

\section{Trade-offs}


Here, two indicators of fishery, i.e. effort and net revenue, are weighted against cod catch (Figure 8). Reducing IQ while allowing cod discards upholds effort, net revenue and cod catches for both fleets (Figure $8 \mathrm{a}$ and c). The slight decrease in net revenue (from ca. $420.000 €$ to ca. $373.000 €$ ) for trawlers can be related to reduced cod landings.

In contrast, imposing a discard ban clearly affects both indicators and cod catch (Figure 8b and d). When IQ is below a ton, fishers stay in port and do not generate revenue. Setting a low IQ ensures that fishers avoid cod catches by targeting other commercial species with lower market value (e.g. mackerel) in more distant fishing grounds. Consequently, a trawler generates less revenue (ca. 73.000€) in proportion to the amount of fishing effort (ca. 44 DAS at an IQ of 2 tons). At an IQ of 4 tons, trawlers allocate some fishing effort to cod fishing grounds, increasing the catch of cod to 1 ton. Effort doubles (88DAS), while net revenue almost triples (211.000€). As more quota is made available, effort increases and levels off at about 110 D AS. This increase in effort leads to an increased cod catch, because gradually more cod fishing grounds are fished. In addition, landings of commercially valuable and cooccurring species such as whiting increase likewise and contribute substantially to the revenue. Hence, while effort levels off, net revenue continues to increase until the point where IQ are no longer constraining i.e. 18 tons.

Trade-offs as seen with trawlers are less observed for netters. Increasing IQ to one ton, fishing (58 DAS) resumes, generating revenue (ca. 135.000€) by fishing for sole and plaice while cod catches remain substantially low $(<6 \mathrm{~kg})$. With higher IQ, effort and net revenue level off to 107DAS and ca. $270.000 €$, respectively. Revenue is maintained regardless the height of IQ, indicating that netters are to an extent economically independent of cod catches when avoiding the use of a gillnet. Netters mainly generated revenue by fishing for sole and plaice, while whiting and cod are by-catch species. 
In general, permitting cod discarding, fishers will uphold effort and maintain their net revenue at the expense of cod conservation. In contrast, with a discard ban, fishers avoid cod but maintain a reduced fishing effort targeting lower valued species such as mackerel to compensate the loss in revenue.

\section{Over-quota fine}

The results above assumed that the discard ban was fully enforced, corresponding to a very high fine. The response of the fishers in terms of over-quota discarding of cod for a range of different fines is shown in Figure 9. With a low fine equal to the market value of cod $(2.43 €$ per kg) trawlers start discarding when IQ are below nine tons. Above this level, fishers have sufficient quota available to uphold their revenue and switch to other target species when their quota is fully exploited. Increasing the fine shifts the threshold IQ below which fishers start discarding the over-quota catch towards a lower level. In our model, the fine needs to be sufficiently high, e.g. 20 times the price of cod, to reduce discarding of over-quota cod below 6 tons.

\section{Discussion}

This study explored the effects of a discard ban in combination with individual quota in mixed fisheries. Under a management regime that allows over-quota discarding, quota for bycatch species such as cod may have little effect on the effort allocation, and catch composition of fishing fleets. Fish that is caught without quota provision are discarded. IQ management with a discard ban can reduce over-quota discarding of cod when properly enforced. In that case, fishers will reallocate effort to fishing grounds and weeks when the cod catch is low at the expense of lower revenue.

The methods and results of this study will be generally applicable for mixed fisheries systems because the main results will not be affected by a number of simplifying assumptions necessary in our modelling approach, but the results cannot be directly applied in the 
management of the Channel fisheries. First, we assume that catching fish in an area has no effect on the amount of fish available in that area later in the year. Second, only variable costs related to fuel use were incorporated. In addition, these fuel costs were set at about $35 \%$ of gross revenue, whereas operating costs of gill-netters and beam trawlers are estimated to be $20 \%$ and 50\%, respectively (Marchal et al. 2011). If costs are higher fishers may spend less time at sea or fish closer to port (Poos et al. 2010). Hence, differences in fuel costs may influence the catch composition and discard rate. Third, revenue was determined by the modelled six species, although other commercially valuable species including squid, sea bass and herring also contribute to the revenue. Fourth, the quota system imposed on the French eastern Channel fisheries is more complicated than the system of individual quota explored with our model. In France, yearly quotas are allotted to public organisations and are either distributed to members (individual quota), or are available for all fishers, in which case it is competitive (generating a race for fish). Both mechanisms occur, and we lack precise quantitative information on how much each one occurs and for which species. In that sense, we also assume that only cod quota affect behaviour, while in reality also other species are managed by quota. Fifth, we considered the study area as a single management unit, although it belongs to two different management units (subdivisions IVc and VIId). Since 2009 the eastern English Channel (subdivision VIId) was allocated a separate cod TAC (i.e. 1600 tons in 2011) from the North Sea (subdivision IV) cod TAC (i.e. 26800 tons) (ICES 2011) and the French fleet receives a larger proportion of cod TAC (ca. 84\%) in VIId, compared to that in IV (ca. 4\%). Finally, we did not account for physical (e.g. depth, substrate) and natural (e.g. weather, wave height) elements of the environment making certain areas inaccessible to certain fleets or métiers. Due to these assumptions results may not fully correspond to the observed data. If we want to adjust the model to make it operational for practical use then the management questions should be specified first, because they will dictate the amount of detail 
required in the model. As indicated above, better understanding of the economic costs and returns and a more detailed implementation of the management regulations are likely candidates for addressing specific management questions.

Our model showed that, when forced by a fine, fishers have to some extent the ability to avoid over-quota discarding by reallocating their effort in space and time. Empirical support for this response comes from Branch \& Hilborn (2008) and Branch (2009), who showed that when TACs were increased for some species and reduced for others, fishers were able to adjust the species mixture in their catches by reallocating their fishing effort. In the eastern Channel, landings of non-regulated species such as striped red mullet (Mullus surmuletus), sea bass (Dicentrarchus labrax) and squid (Loligo spp.) have increased following the decline of cod landings and may reflect a response of fishers to the change in resource composition (Carpentier et al. 2009).

An important consideration when exploring management regulations is the compliance of fishers to regulations. Results show that compliance of the fishery to restrictive quota is influenced by the fine for overshooting the IQ. The fine as currently imposed in our model does not explicitly penalizes discarding, but applies to overshooting the specified maximum landing quotas. We hypothesise that the fine for discarding should be equal to the fine for over-quota landings minus the fish price to have similar effects in the observed patterns. This hypothesis results from the observation that the difference between discarding and overquota-landing is the price of the over-quota fish. Our results indicate that fines, in order to be efficient, should be much higher than fish price. Imposing a high fine would be a contributing factor to deter fishers from rule-breaking behaviour (Bose \& Crees-Morris 2009, Jagers et al. 2012). In our model, we assume a $100 \%$ detection rate while realistically rule-breaking behaviour of fishers may not necessarily be detected. This implies even higher fines should 
be considered to obtain full fisheries compliance. Yet, assessing the risk of being detected is beyond the scope of this paper.

Catches in this study are estimated on the basis of landings per unit effort of French commercial vessels. High resolution estimates of spatial and temporal distribution from independent sources like scientific research surveys are lacking for this area. The drawback of using commercial landing data of stocks which are managed with TAC remains the lack of information on high-grading, over-quota discarding and misreported catches (Rijnsdorp et al. 2007). Due to this missing information estimated catches may suffer a degree of bias, especially for species with a restrictive TAC such as cod (Ulrich et al. 2011).

In this study we have focussed only on one component of the discard problem, the over-quota discarding. Fishers may also be forced to discard catches below the minimum landing size (MLS) or discard non-commercial species. These discards are particularly high in mixed fisheries that target multiple species with different selectivity characteristics relative to the minimum landing size, such as in the roundfish, flatfish and Norway lobster fisheries (Rijnsdorp \& Millner 1996, Cappell 2001, Catchpole et al. 2005). By ignoring these other discards, we will underestimate the overall level of discarding in these fisheries (Gillis et al. 1995a, Poos et al. 2010, Depestele et al. 2011).

The DSVM approach could also be applied to the problem of high-grading as well as discarding undersized and non-commercial fish. Here, each species was modelled as a homogeneous group of marketable fish, but key descriptors such as abundance, catch and market price could be classified into different size classes in the future. Also, by including price dynamics into a stochastic dynamic programming model the behavioural response of fishers towards market value fluctuations may be studied (Dowling et al. 2012). Like many other studies of fishers' behaviour we have presumed that fishers are entirely driven by economic interests (Gordon 1953, Hilborn \& Walters 1987, Poos et al. 2010). The relevance, 
however, of tradition, past experiences and information exchange on fishers' behaviour (Holland \& Sutinen 2000, Little et al. 2004, Marchal et al. 2009) could be taken into account. Currently most of the advice in mixed-fisheries is based on single-stock biological objectives (e.g. keep species above a certain biomass, obtain desired fishing mortality), although in a mixed fisheries context the single species objectives cannot be achieved for multiple species simultaneously (Gröger et al. 2007, Ulrich et al. 2011, Da Rocha et al. 2012, Rijnsdorp et al. 2012). The model presented in this study allows trade-offs between multiple objectives in a mixed fisheries context. By introducing a length structure or age structure for different species, management scenarios can be tested to estimate (1) the bycatch of undersize commercially important species such as plaice; (2) over-exploitation of vulnerable species and (3) link predictions to existing stock assessment models and contribute to the improvement of mixed fisheries management.

Mechanistic models are increasingly being used to analyse vessel fishing behaviour (Little et al. 2004, Poos et al. 2010, Dowling et al. 2011). Commonly, fishers behaviour is based on economic interests while alternative utility functions with less emphasis on economic interests, such as tradition or information sharing could be included (Little et al. 2009). However, this would require a more extensive understanding of the rationale of fishers' behaviour. Fisheries management is a complex system, whereby a manager must take interests and concerns of many stakeholders into account. Our spatially explicit effort allocation model proves to be a useful tool to evaluate conservation and economic trade-offs and enables managers to visualize consequences of new management scenarios, such as a discard ban. Hence, our conclusions are important for fisheries in Europe as well as fisheries globally, contributing to an Ecosystem Approach to Fisheries Management (EAFM) where one tries to mitigate overfishing and low economic resilience of the fishing industry.

\section{Acknowledgements}


This research was supported by the European Community's Seventh Framework Programme (FP7/2007-2013) under Grant Agreement No. 266445 for the project Vectors of Change in Oceans and Seas Marine Life, Impact on Economic Sectors (VECTORS).

\section{References}

Alverson DL, Freeberg MH, Murawski SA, Pope GJ (1994) A global assessment of fisheries bycatch and discards. FAO Fish Tech Pap 339

Anon. (2011) High level meeting on ba nning discards. Brussels $1 \mathrm{M}$ arch 2011Non paper Brussels: Commission of the European Communities:4 pp.

Bose S, Crees-Morris A (2009) Stakeholder's views on fisheries compliance: An Australian case study. Mar Policy 33:248-253

Branch TA (2009) How do individual transferable quotas affect marine ecosystems? Fish Fish 10:39-57

Branch TA, Hilborn R (2008) Matching catches to quotas in a multispecies trawl fishery: targeting and avoidance behavior under individual transferable quotas. Can J Fish Aquat Sci 65:1435-1446

Buisman FC, Bakker T, Bos E, kuhlman T, Poos JJ (2011) Effecten van een verbod op discards in de Nederlandse platvisvisserij. LEi-rapport 2011-014

Cappell R (2001) Economic aspects of discarding - UK case study: Discarding by North Sea Whitefish Trawlers. In: Final report for DG Fish, European Communities, and MAFF. UK: Nautilus Consultants, Edinburgh

Carpentier A, Coppin F, Dupuis L, Engelhard G, Gardel L, Martin C, Meaden G, Morin J, Rostiaux E, Vaz S, Vérin Y, Walton J (2009) chap. 5, P artie "Engins, navires \& resources halieutiqueexploitées"/ section"Gears, vessels \& exploited species". In Carpentier A, Martin CS, Vaz S (eds), Channel Habitat Atlas for Marine Resource Management, final report (CHARM phase II):626 pp. \& CD-rom 
Catchpole TL, Frid CLJ, Gray TS (2005) Discarding in the English north-east coast Nephrops norvegicus fishery: the role of social and environmental factors. Fish Res 72:45-54

Clark CW, Butler RW (1999) Fitness components of avian migration: A dynamic model of Western Sandpiper migration. Evol Ecol Res 1:443-457

Clark CW, Mangel M (2000) Dynamic state variable models in ecology: Methods and applications, Vol. Oxford University Press

Da Rocha J-M, Gutiérrez M-J, Cerviño S (2012) Reference points based on d ynamic optimization: a versatile algorithm for mixed-fishery management with bioeconomic age-structured models. ICES J Mar Sci 69:660-669

Depestele J, Vandemaele S, Vanhee W, Polet H, Torreele E, Leirs H, Vincx M (2011) Quantifying causes of discard variability: an indispensable assistance to discard estimation and a paramount need for policy measures. ICES J Mar Sci 68:1719-1725

Diamond B, Beukers-Stewart BD (2011) Fisheries Discards in the North Sea: Waste of Resources or a Necessary Evil? Rev Fish Sci 19:231-245

Dowling NA, Wilcox C, Mangel M, Pascoe S (2011) Assessing opportunity and relocation costs of marine protected areas using a behavioural model of longline fleet dynamics. Fish and Fisheries:13(2): 139-157

FAO (2008) The state of world fisheries 2008. State of World Fisheries and Aquaculture SOFIA 2008196

Gillis DM (2003) Ideal free distributions in fleet dynamics: a behavioral perspective on vessel movement in fisheries analysis. Can J Zool 81:177-187

Gillis DM, Peterman RM, Pikitch EK (1995a) Implications of Trip Regulations for High Grading - a Model of the Behavior of Fishermen. Can J Fish Aquat Sci 52:402-415

Gillis DM, Pikitch EK, Peterman RM (1995b) Dynamic discarding decisions - foraging theory for high-grading in a trawl fishery. Behav Ecol 6:146-154 
Gordon HS (1953) An economic approach to the optimum utilization of fishery resources. J Fish Res Board Can 10:442 - 457

Graham N, Fryer RJ (2006) Separation of fish from Nephrops norvegicus into a two-tier codend using a selection grid. Fish Res 82:111-118

Gröger JP, Rountree RA, Missong M, Rätz H-J (2007) A stock rebuilding algorithm featuring risk assessment and an optimization strategy of single or multispecies fisheries. ICES J Mar Sci 64:1101-1115

Hilborn R, Kennedy RB (1992) Spatial pattern in catch rates - a test of economic-theory Bull Math Biol 54:263-273

Hilborn R, Walters CJ (1987) A general-model for simulation of stock and fleet dynamics in spatially heterogeneous fisheries. Can J Fish Aquat Sci 44:1366-1369

Holland DS, Sutinen JG (2000) Location choice in New England trawl fisheries: Old habits die hard. Land Econ 76:133-150

Houston AI, McNamara JM (1999) Models of Adaptive Behaviour, Vol. Cambridge University press

ICES (2010) Report of the ICES Advisory Committee 2010. In: ICES Advice, 2010, Book Book 6,

ICES (2011) Report on the ICES Advisory Committee 2011. In: ICES Advice, 2011, Book Book 6,

Jagers SC, Berlin D, Jentoft S (2012) Why comply? Attitudes towards harvest regulations among Swedish fishers. Mar Policy 36:969-976

Kelleher K (2005) Discards in the world's marine fisheries. An update. FAO Fish Tech Pap T470:131

Kraak SBM, Bailey N, Cardinale M, Darby C, De Oliveira JAA, Eero M, Graham N, Holmes S, Jakobsen T, Kempf A, Kirkegaard E, Powell J, Scott RD, Simmonds EJ, Ulrich C, 
Vanhee W, Vinther M (2012) Lessons for fisheries management from the EU cod recovery plan. Mar Policy, DOI 10.1016/j.marpol.2012.05.002

Kristofersson D, Rickertsen K (2005) High-Grading in a Quota-Regulated Fishery, with Empirical Evidence from the Icelandic Cod Fishery. In: European Association of Agricultural Economists 2005 International Congress, August 23-27, 2005, Copenhagen, Denmark

Kristofersson D, Rickertsen K (2009) Highgrading in Quota-Regulated Fisheries: Evidence from the Icelandic Cod Fishery. Am J Agric Econ 91:335-346

Little LR, Kuikka S, Punt AE, Pantus F, Davies CR, Mapstone BD (2004) Information flow among fishing vessels modelled using a Bayesian network. Environ Model \& Softw $19: 27-34$

Little LR, Punt AE, Mapstone BD, Begg GA, Goldman B, Williams AJ (2009) An agentbased model for simulating trading of multi-species fisheries quota. Ecol Model $220: 3404-3412$

Mangel M (1987) Oviposition site selection and clutch size in insects. J Math Biol 25:1-22

Marchal P, Lallemand P, Stokes K (2009) The relative weight of traditions, economics, and catch plans in New Zealand fleet dynamics. Can J Fish Aquat Sci 66:291-311

Marchal P, Little LR, Thebaud O (2011) Quota allocation in mixed fisheries: a bioeconomic modelling approach applied to the Channel flatfish fisheries. ICES J Mar Sci 68:15801591

Messina G, Notti E (2007) Energy Saving In Trawlers: Practical And Theoretical Approaches. In: ICMRT 2007 Final Report

Poos JJ, Bogaards JA, Quirijns FJ, Gillis DM, Rijnsdorp AD (2010) Individual quotas, fishing effort allocation, and over-quota discarding in mixed fisheries. ICES J Mar Sci 67: 323-333. 
Poos JJ, Rijnsdorp AD (2007) An "experiment" on effort allocation of fishing vessels: the role of interference competition and area specialization. Can J Fish Aquat Sci 64:304313

Rijnsdorp AD, Daan N, Dekker W (2006) Partial fishing mortality per fishing trip: a useful indicator of effective fishing effort in mixed demersal fisheries. ICES J Mar Sci $63: 556-566$

Rijnsdorp AD, Daan N, Dekker W, Poos JJ, Van Densen WLT (2007) Sustainable use of flatfish resources: Addressing the credibility crisis in mixed fisheries management. $\mathbf{J}$ Sea Res 57:114-125

Rijnsdorp AD, Millner RS (1996) Trends in population dynamics and exploitation of North Sea plaice (Pleuronectes platessa L) since the late 1800s. ICES J Mar Sci 53:11701184

Rijnsdorp AD, van Overzee HMJ, Poos JJ (2012) Ecological and economic trade-offs in the management of mixed fisheries: a case study of spawning closures in flatfish fisheries. Mar Ecol Prog Ser 447:179-194

Salas S, Gaertner D (2004) The behavioural dynamics of fishers: management implications. Fish Fish 5:153-167

Taal C, Bartelings H, Beukers R, Duijn vAJ, klok AJ, Oostenbrugge vJAE, Smit JPG (2009) Visserij in cijfers 2009. In, Book Rapport 2009-070. Landbouw Economisch Instituut Den Haag

Ulrich C, Reeves SA, Vermard Y, Holmes SJ, Vanhee W (2011) Reconciling single-species TACs in the North Sea demersal fisheries using the Fcube mixed-fisheries advice framework. Ices Journal of Marine Science 68:1535-1547

Ulrich C, Wilson DCK, Nielsen JR, Bastardie F, Reeves SA, Andersen BS, Eigaard OR (2012) Challenges and opportunities for fleet- and métier-based approaches for 
fisheries management under the European Common Fishery Policy. Ocean Coast Manage, DOI 10.1016/j.ocecoaman.2012.06.002

Vaz S, Carpentier A, Coppin F (2007) Eastern English Channel fish assemblages: measuring the structuring effect of habitats on distinct sub-communities. ICES J Mar Sci 64:271287

Wood, SN. (2006). Generalized Additive Models, An Introduction with R. London: Chapman and Hall.

Zuur AF, Ieno EN, Walker NJ, Saveliev AA, Smith GM (2009) Mixed effect models and extensions in ecology in R, Vol, New York 


\section{Tables}

Table 1. Proportion of six commercial species in the catch composition of both fishing fleets, separated by métiers (OTB_D: demersal otter trawl, OTB_M: mixed demersal/pelagic trawl, TN: trammel net. GN: gillnet).

Table 2. Model components used to describe variation in landing rates. Variables métier and year are discrete variables and engine power, mesh size, latitude and longitude (based on geographic midpoint of the ICES rectangle) and day of the year (DoY) are continuous variables. The term fleet represents a segregation of the fleet by trawlers or netters. The term $k$ denotes the maximum number of knots in each smoothing.

Table 3. Summary of parameter values included in the model.

Table 4. Description of scenarios.

Table 5. Model selection results for the six species, based on the Bayesian Information Criterion (BIC). Numbers indicate the difference between the previous obtained BIC associated with the previous variable, and the newly acquired BIC of the newly selected variable. If negative, the variable is excluded from the best model. For the model descriptions the offset has been omitted. The estimated theta $(\theta)$ is also given. * The letters are referenced by the letters used for the variables in Table 2 .

\begin{tabular}{lcccc}
\hline & \multicolumn{2}{c}{ Otter trawl } & \multicolumn{2}{c}{ Static net } \\
\hline & OTBD & OTBM & TN & GN \\
Sole (\%) & 0.4 & 0 & 54.9 & 14.8 \\
Plaice (\%) & 4.1 & 2.1 & 15.4 & 15.7 \\
Cod (\%) & 5.3 & 2.6 & 8 & 45.3 \\
Mackerel (\%) & 15.6 & 44.9 & 0 & 0 \\
Whiting (\%) & 29.4 & 12.1 & 0.9 & 2.7 \\
Mullet (\%) & 6.8 & 4.0 & 0.1 & 0.1 \\
Other (\%) & 38.3 & 34.1 & 20.6 & 21.4 \\
\hline
\end{tabular}

\section{Table 1}




\begin{tabular}{lllr}
\hline Nominator & Model component & Description & $k$ \\
\hline$A$ & Métier & Effect of métier & - \\
$B$ & Year & Effect of year & - \\
$C$ & $f($ engine power|fleet $)$ & Effect of engine power by fleet & 4 \\
$D$ & $f($ Mesh sizelfleet $)$ & Effect of mesh size by fleet & 4 \\
$E$ & $f($ DoY $)$ & Variability in time & 4 \\
$F$ & $f($ lat,$l o n)$ & Variability in space & 4 \\
$G$ & $f($ lat, lon,DoY $)$ & Variability in catch rates in space and time & 5 \\
\hline
\end{tabular}

Table 2

629

\begin{tabular}{lcc}
\hline & Trawl & Net \\
\hline Engine power $(\mathrm{kW})$ & 440 & 160 \\
Mesh Size $(\mathrm{mm})$ & 80 & 90 \\
Fuel costs per day $(€)$ & 1800 & 1300 \\
Fishing effort (hours) & 75 & 72
\end{tabular}

Market value (€ per kg)

\begin{tabular}{ll} 
Sole & 9.42 \\
Cod & 2.43 \\
Plaice & 1.99 \\
Whiting & 1.40 \\
Mackerel & 0.99 \\
Mullet & 5.40 \\
\hline
\end{tabular}

Table 3

631

\begin{tabular}{llcc}
\hline Scenario & Fleet & Individual cod quota $\left(\mathrm{t} \mathrm{y}^{-1}\right)$ & Fine $\left(€ \mathrm{~kg}^{-1}\right)$ \\
\hline Discard ban & Trawlers & $0-27$ & $2.43-200$ \\
& Netters & $0-20$ & 0 \\
\hline Discards allowed & Trawlers & $0-27$ & \\
& Netters & $0-20$ & \\
\hline
\end{tabular}

Table 4 


\begin{tabular}{llcccccccc}
\hline Species & model structure & BIC1 & BIC2 & BIC3 & BIC4 & BIC5 & BIC6 & BIC7 & Theta $(\theta)$ \\
\hline Cod & intercept + D + G + B + C + A + E + F & 7095.8 & 2845.9 & 1554.5 & 1636.7 & 663.0 & 121.3 & -1.5 & 0.185 \\
Plaice & intercept + C + A + G + B + D + E + F & 18002.6 & 3205.2 & 3119.3 & 932.6 & 324.3 & 290.4 & -1.4 & 0.393 \\
Sole & intercept + A + C + G + B + D + E + F & 22990.1 & 12189.5 & 886.6 & 444.4 & 258 & 118.7 & -4.6 & 0.193 \\
Whiting & intercept + C + G + A + D + B + F + E & 5302.3 & 6073.5 & 1044.2 & 299.3 & 40.5 & 0.2 & -8.7 & 0.252 \\
Mackerel & intercept + A + G + C + B + D + E + F & 15575.5 & 3143.5 & 2272.3 & 402 & 279.9 & 10.5 & -1.7 & 0.234 \\
Mullet & intercept + C + G + E + B + A + D + F & 5415.7 & 4104.7 & 2293.9 & 1580.1 & 360.7 & 170.1 & -1.2 & 0.231 \\
\hline
\end{tabular}

$637 \quad$ Table 5 


\section{Figures}

Figure 1. Map of the eastern English Channel (i.e. 27E9 up to 30F1) and southern North Sea (i.e. $31 \mathrm{~F} 1$ up to $32 \mathrm{~F} 3$ ), showing the areas where both fleets may fish. The star indicates the location of the port of Boulogne-Sur-Mer.

Figure 2. Modelled average annual cod catches (i.e. landings plus discards) per vessel for both trawlers and netters in relation to the available individual cod quota (dashed blue line). Upper panels (a) and (b) are for trawlers; lower panels (c) and (d) for netters. In the left panels (a) and (c) discarding is allowed, while in the right panels (b) and (d) discarding is banned. Average annual landings (black line) with confidence area (dark grey shaded area) are separated from average annual cod catches (light grey line) with confidence area (light grey shaded area), depicting the amount of cod discards.

Figure 3. M odelled temporal variation in cod catches for both management scenarios at individual quota of 3,6 and $9 \mathrm{t} \mathrm{y}-1$, including a fine equal to $200 € \mathrm{~kg}^{-1}$. The average cod catch of an individual trawler (a-c) or netter (d-f) per biweekly time-step is illustrated. The shaded area quantifies cod discards, being the difference between cod catches (dashed black line) and cod landings (black line), when discarding is allowed. The dashed red line indicates cod catches when a discard ban is imposed.

Figure 4. Modelled average annual effort per vessel for both fleets and both management scenarios. Upper panels (a) and (b) are for trawlers; lower panels (c) and (d) for netters. The left panels (a) and (c) allow discarding, while the right panels (b) and (d) ban discarding. The area between the upper (95\%) and lower (5\%) confidence intervals is shaded.

Figure 5. M odelled spatial allocation of effort by average number of trips per year for trawlers (a-d) and netters (e-h) at low $\left(5 \mathrm{t} \mathrm{y}^{-1}\right)$ and high $\left(15 \mathrm{t}^{-1}\right)$ individual cod quota. Upper graphs ( $a-b$ and e-f for trawlers and netters, respectively) are based on the first management 
scenario (discarding), while lower graphs (c-d and g-h) are based on scenarios with a discard ban.

Figure 6. The proportion of effort allotted to each métier operated by trawlers, when constrained by a discard ban (light grey: mixed demersal/pelagic trawl, dark grey: demersal otter trawl).

Figure 7. The proportion of each of the six species contributing to the total catch for trawlers (a \& b) and netters (c \& d). Right panels (b) and (d) are modelled catch compositions for the first management scenario and left panels (a) and (c) for the second scenario. For each of the six species a different shade is used. The order of the catch composition from top to bottom for trawlers: mullet, mackerel, whiting, cod and plaice; and for netters, sole, cod and plaice.

Figure 8. Trade-offs between $(\boldsymbol{\Lambda})$ net revenue, ( $(\boldsymbol{\bullet})$ effort and cod catches $\left(\mathrm{t}^{-1}\right)$. Panels (a) and (b) present results for trawlers, and (c) and (d) for netters. Left and right panels refer respectively to discard and no-discard scenarios. Note the changing colours of the points from black to light grey, as individual cod quota increases from low to high levels.

Figure 9. Average over-quota cod catches in relation to fine levels. The upper light grey line represents a free-fishing situation (fine $=0$ ). The darker the line the higher the fine, varying from the market value of cod $(2.43 €)$ up to 20 times that market value $(48.60 €)$. The black line with no over-quota catches represents a situation with an extremely high fine $\left(200 € \mathrm{~kg}^{-1}\right)$ for overshooting the quotas. 


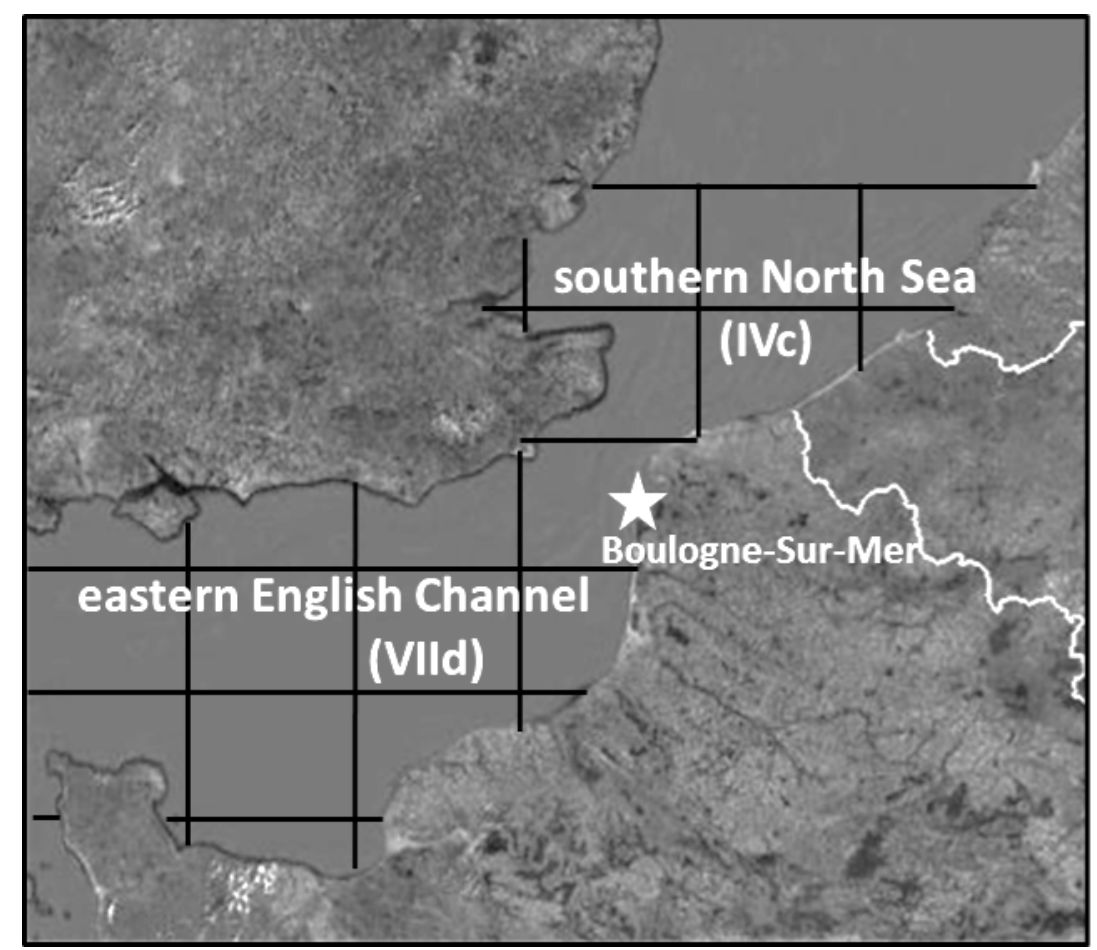

682

Figure 1

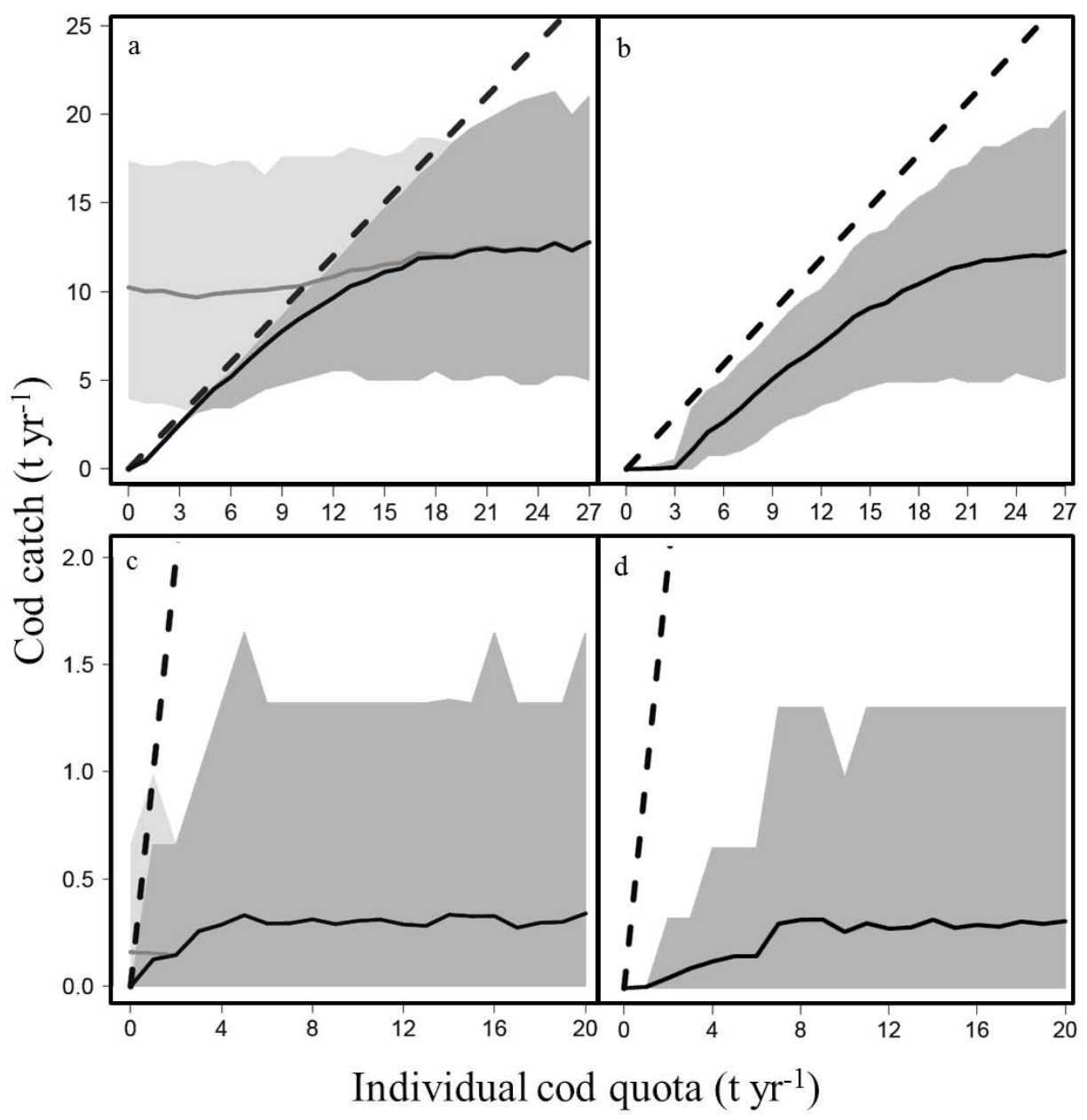

Figure 2 


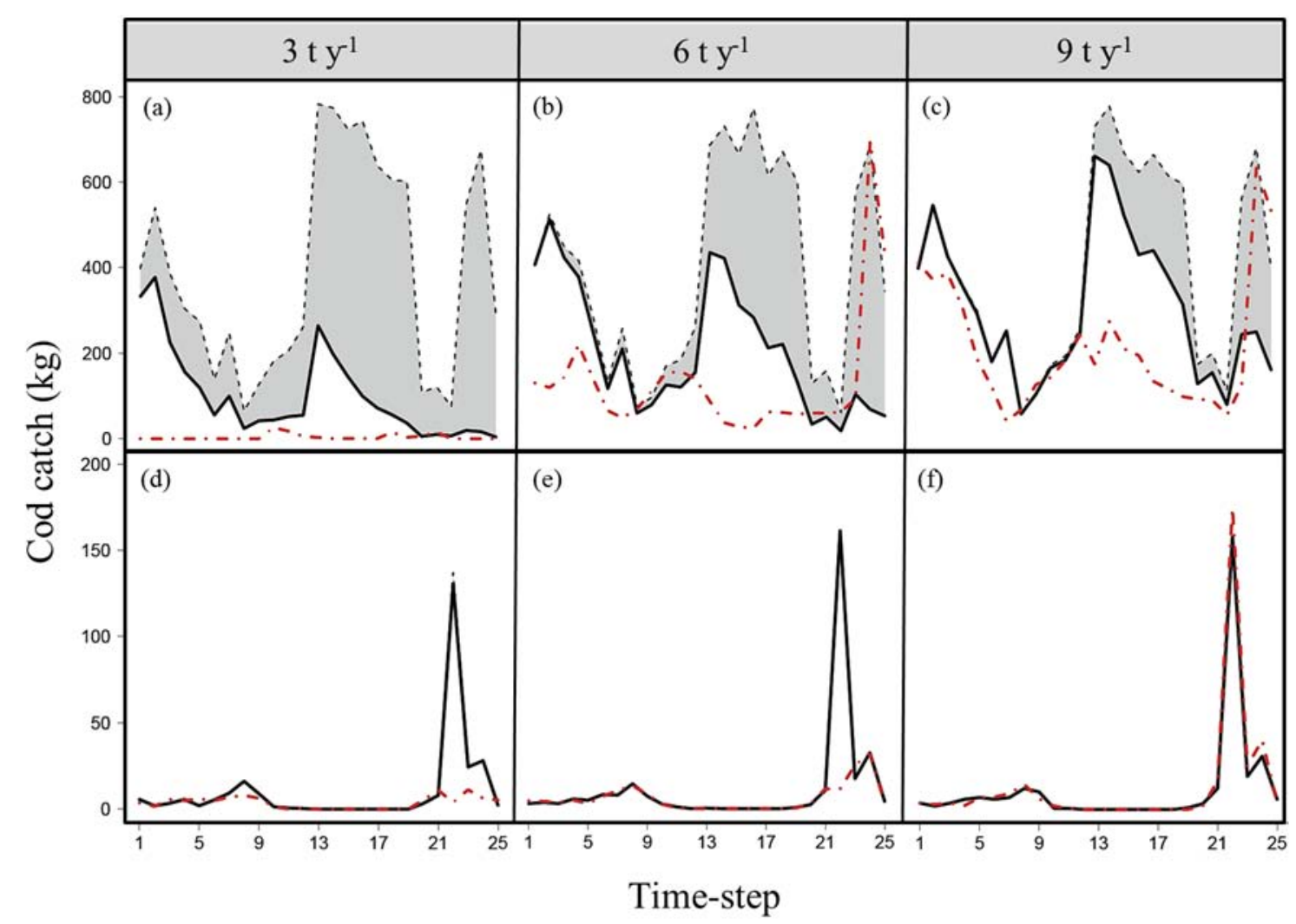

685

Figure 3

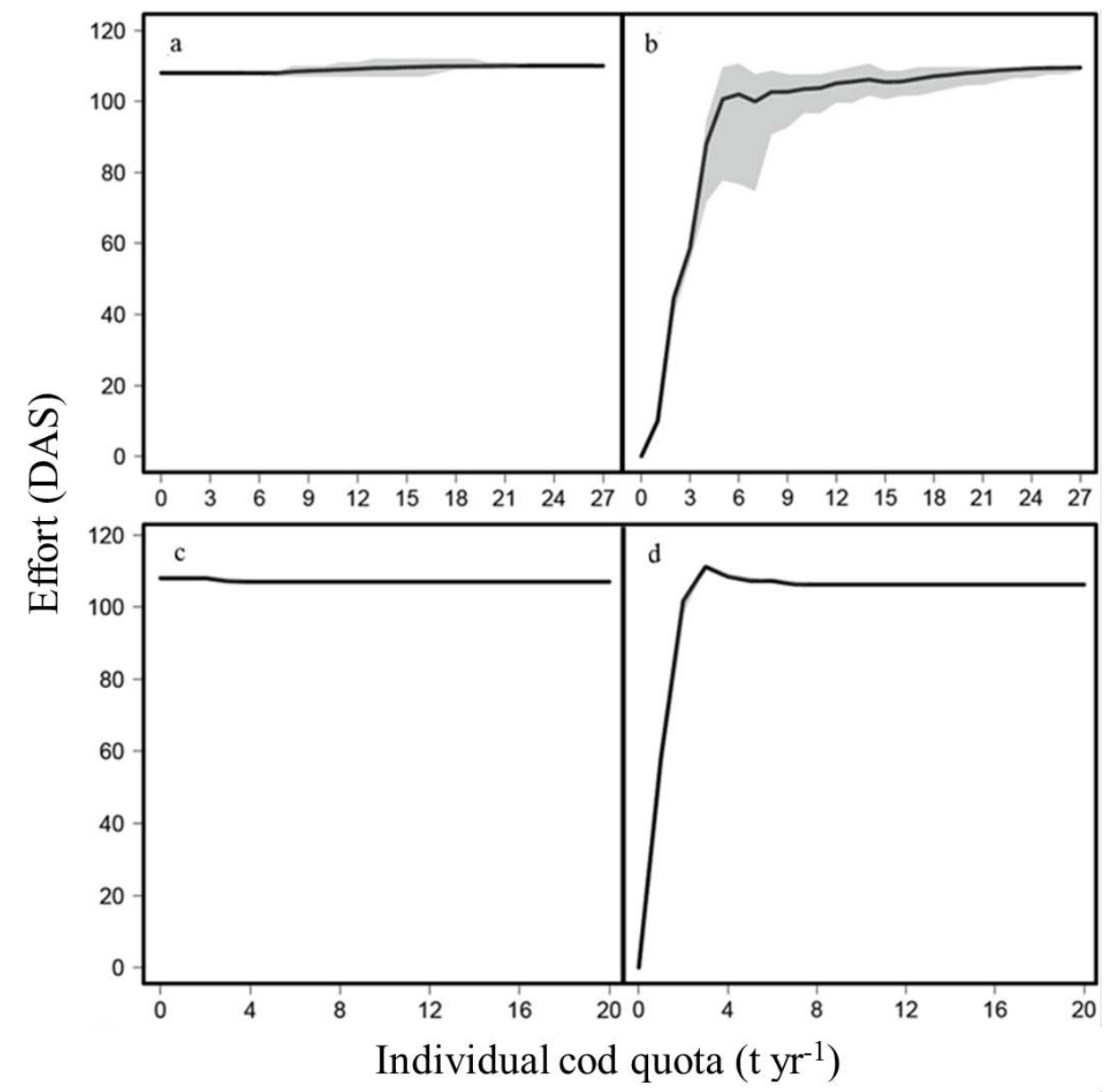


Figure 4
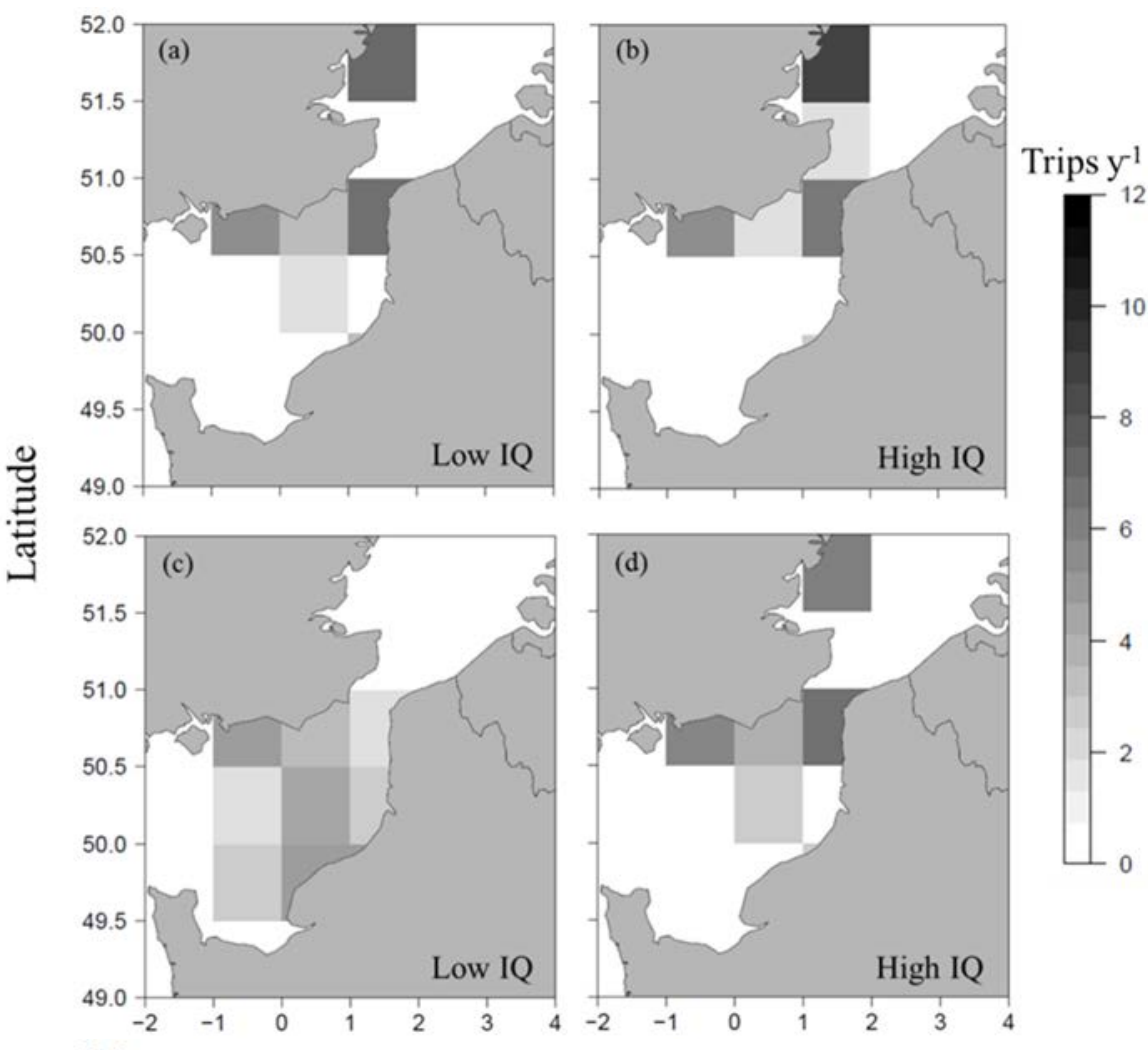

689

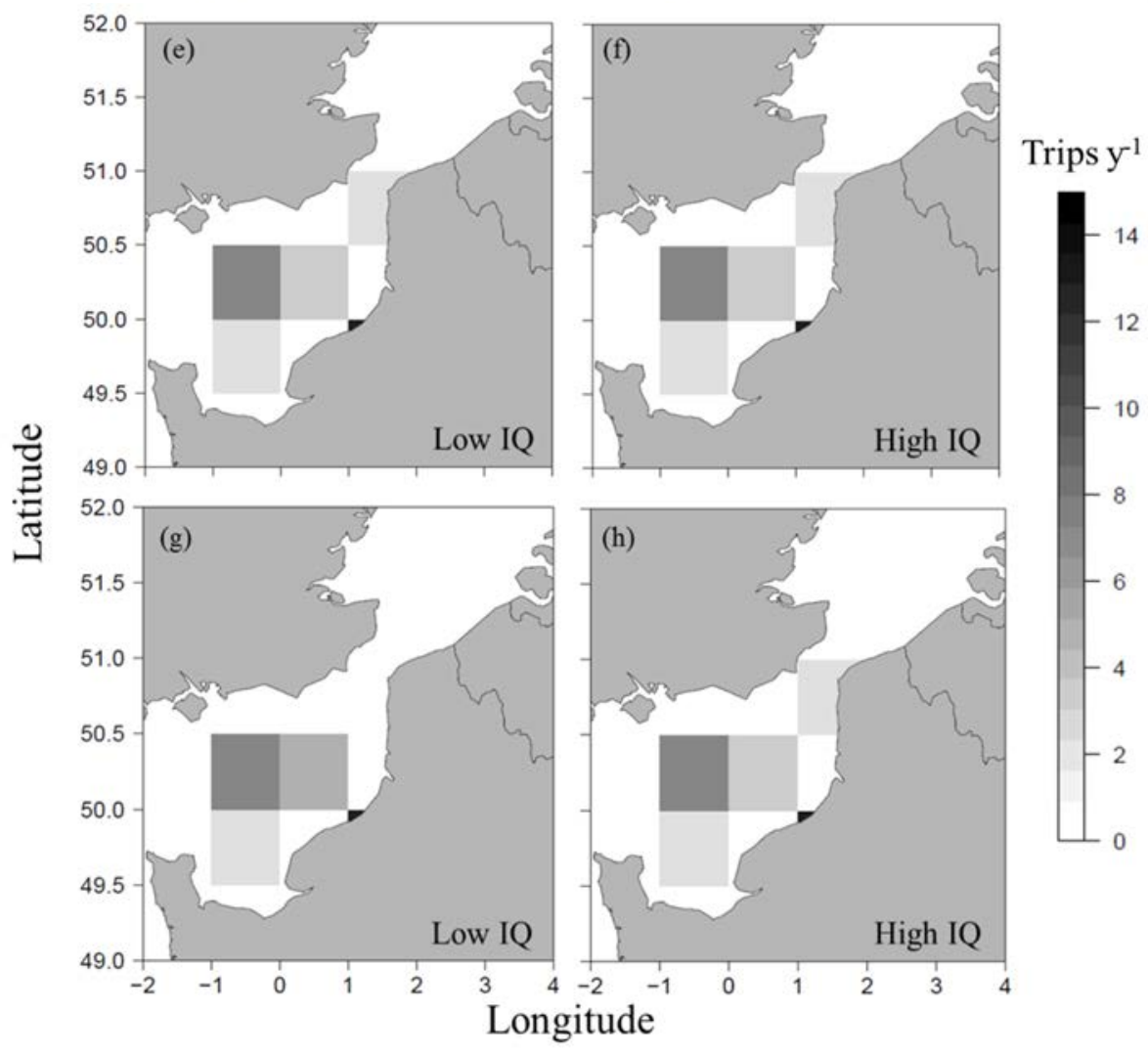

690

Figure 5 


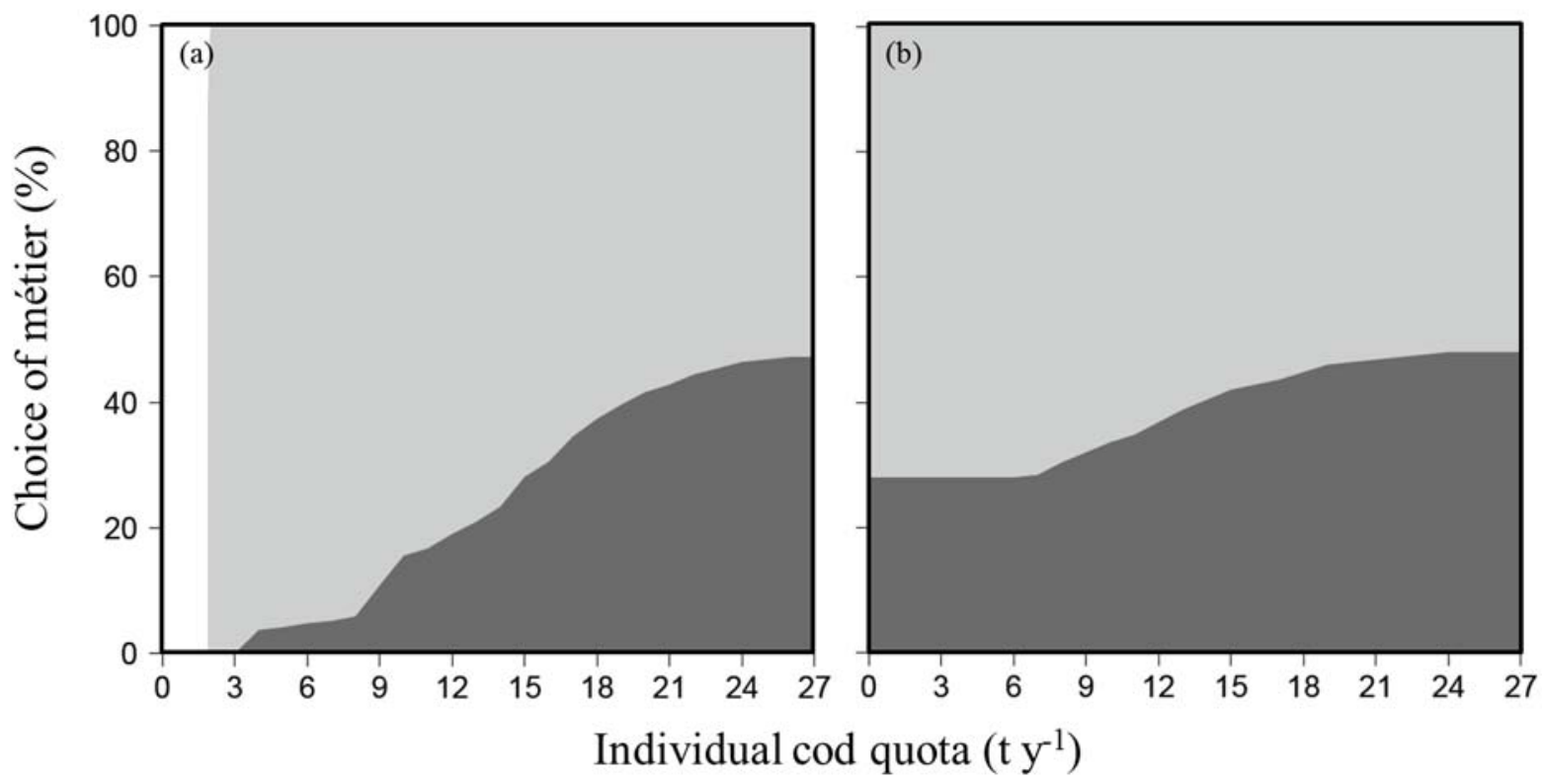

692

Figure 6

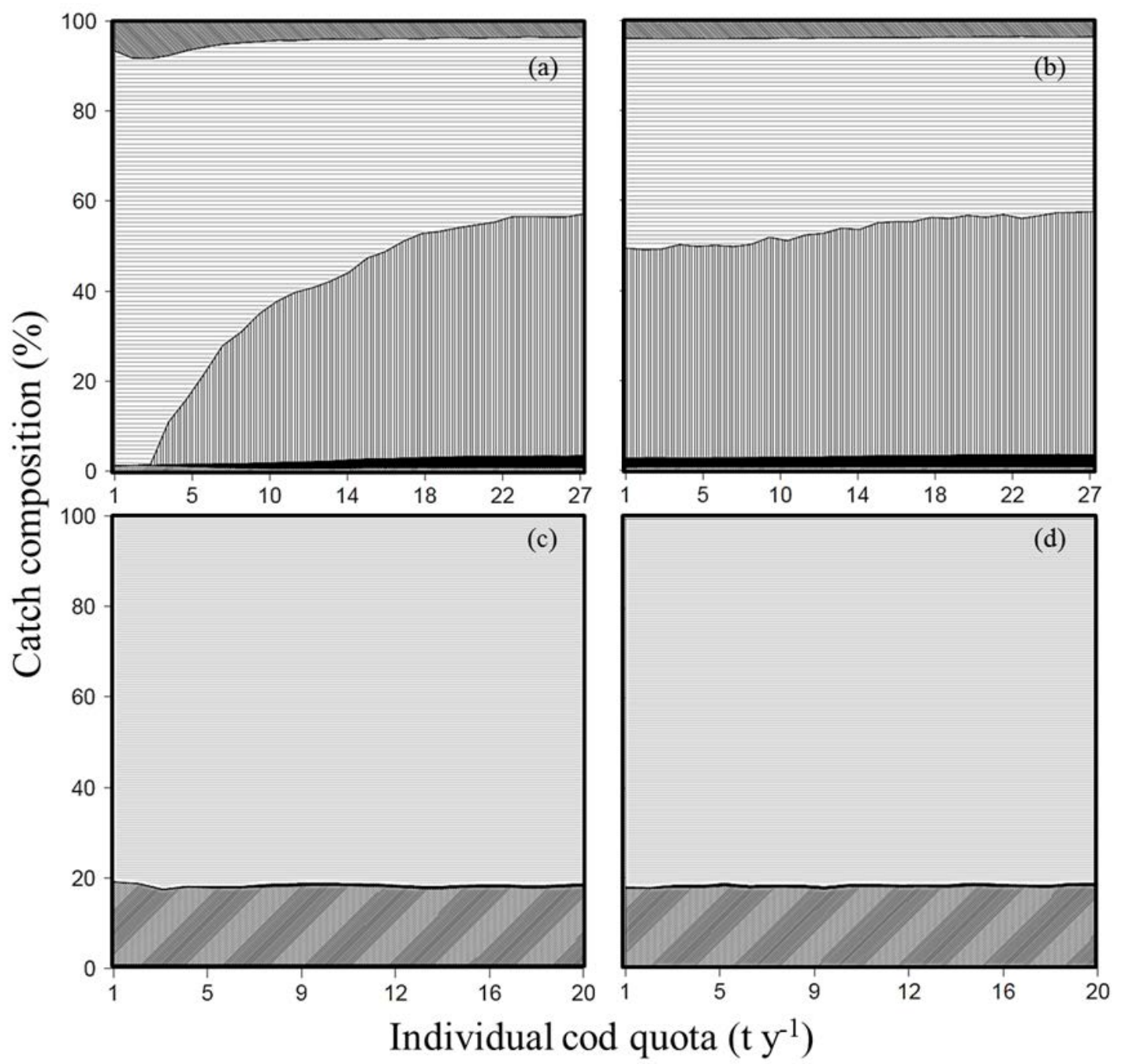

Figure 7

Page | 35 


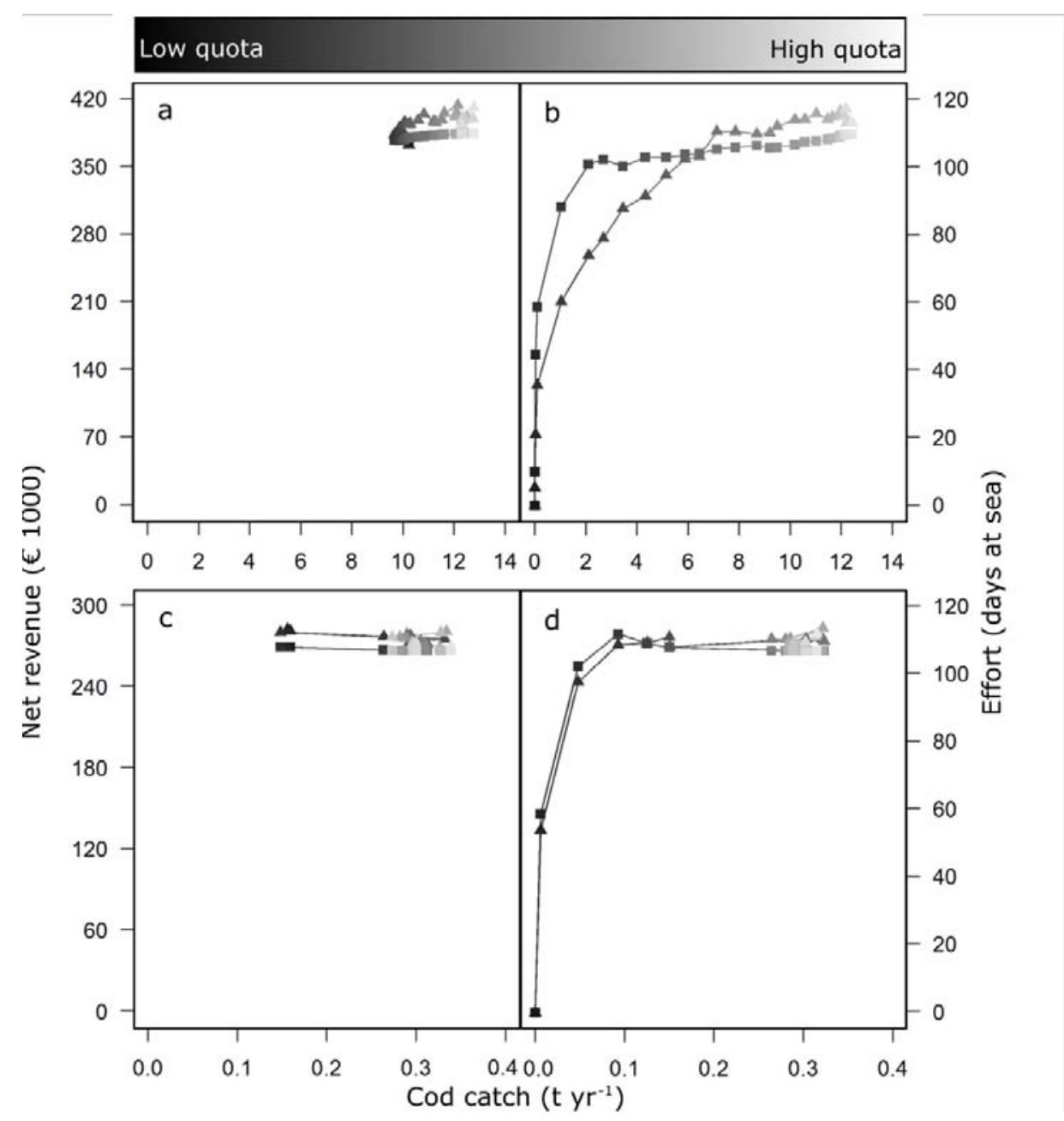

$697 \quad$ Figure 8

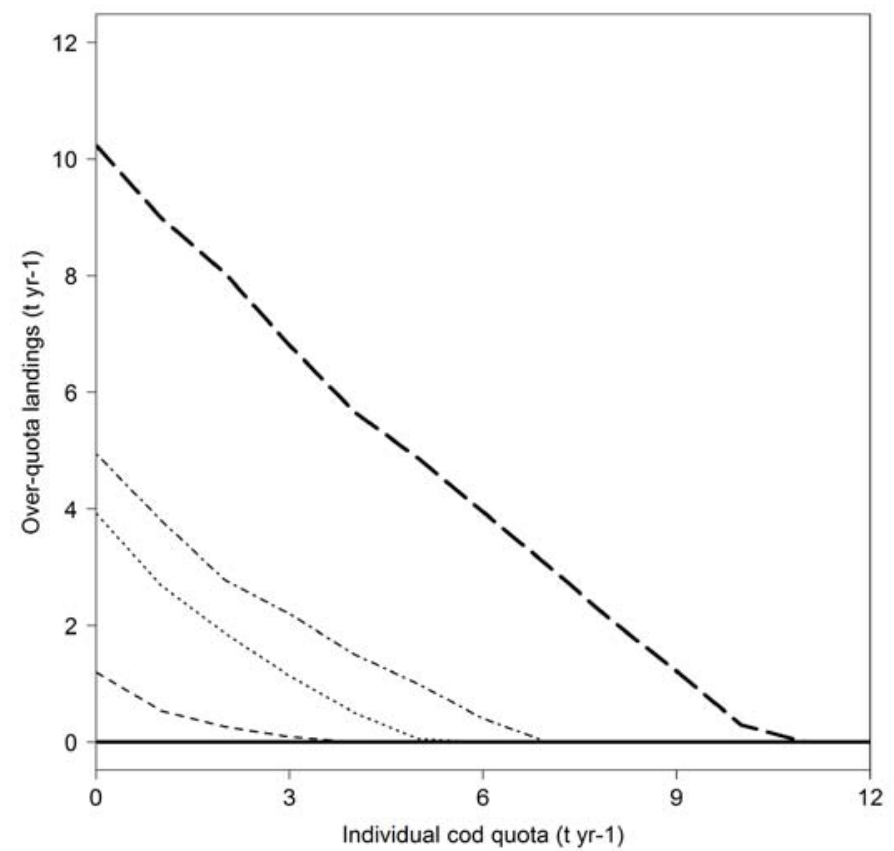

698

Figure 9

Page | 36 